\title{
BROKER SILENCE AND RULE 10b-5: EXPANDING THE DUTY TO DISCLOSE*
}

Ir has long been unclear whether rule 10b-5 of the Securities and Exchange Commission-a broad prohibition of fraudulent practices in securities transactions-imposes liability for total nondisclosure of material information. ${ }^{1}$ A significant expansion of the scope of the rule may therefore have been effected by a recent SEC decision ${ }^{2}$ which imposed an administrative penalty for nondisclosure ${ }^{3}$ on a stockbroker trading for discretionary accounts on dividend information received from a business associate who was a corporate insider. The ruling, moreover, may be a first step in the imposition of a more general duty of disclosure upon the stockbroker.

While the common law clearly imposed liability for misrepresentations and half-truths, ${ }^{4}$ there has been substantial judicial confusion concerning the existence of liability for mere nondisclosure. 5 The general common law rule has been that total silence can not operate as a fraud unless the defendant is, for some special reason, under an affirmative duty of disclosure. ${ }^{b}$ Some courts have derived such a duty from the presence of a fiduciary relationship, ${ }^{7}$ such as that

*In the Matter of Cady, Roberts \& Co., SEC Securities Exchange Act Release No. 6668, Nov. 8, 1961.

1. While it has been clear that misrepresentations and material omissions, or halftruths, fall within the proscription of the rule, there have been few cases involving total

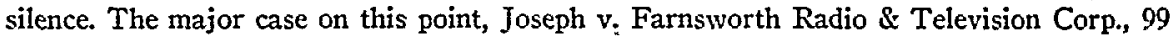
F. Supp. 701 (S.D.N.Y. 1951), did not reach the issue of silence, the case being dismissed on other grounds.

2. In the Matter of Cady, Roberts \& Co., SEC Securities Exchange Act Release No. 6668, Nov. 8, 1961.

3. In one sense, there will never be a case of total non-disclosure regarding securitics. So long as a corporation publishes a financial statement, or issues a prospectus, there will have been some representations made about the company. The silence referred to then is only silence, concerning the company's condition, on the part of one of the parties to a transaction, at the time of the transaction.

4. One is under a duty not only "to state truthfully what he actually tells, but also not to suppress any fact within his knowledge which will materially change or alter the effects of the facts stated." Equitable Life Ins. Co. v. Halsey, Stuart \& Co., 312 U. S. 410, 425 (1941); see also 3 Restatensent, Torts $\$ 529$ (1938); Prosser, Torts 534 (2d ed. 1955).

5. This confusion stems from the common law distinction between misrepresentation and nondisclosure. Whereas the former would provide grounds for a tort action of deceit, the latter would not. See, e.g., Peek v. Gurney, L.R. 6 H.L. 377 (1873).

6. One party to a business transaction is under a duty to exercise reasonable care to disclose to the other before the transaction is consummated

(a) such matter as the other is entitled to know because of a fiduciary or other similar relation of trust and confidence between them . . .

3 Restatement, Torts § 551(2) (1938); see also Prosser, Torts 534-35 (2d ed. 1955).

7. E.g., Hotchkiss v. Fischer, 136 Kan. 530, 16 P.2d 531 (1932) ; Gerdes v. Reynolds, 28 N.Y.S.2d 622 (1941). But see Buckley v. Buckley, 230 Mich. 504, 202 N.W. 955 (1925). 
between corporate insiders and noncontrolling stockholders; ${ }^{8}$ others have derived this duty from "special circumstances" requiring affirmative disclosure -a criterion similar in practice to the first. ${ }^{9}$

Rule $10 \mathrm{~b}-5,{ }^{10}$ promulgated by the Securities and Exchange Commission pursuant to section 10(b) of the Securities Exchange Act of 1934, ${ }^{11}$ declares it to be unlawful:

for any person, directly or indirectly, by the use of any means or instrumentality of interstate commerce, or of the mails, or of any facility of any national securities exchange

(a) to employ any device, scheme, or artifice to defraud,

(b) to make any untrue statement of a material fact or to omit to state a material fact necessary in order to make the statements made, in light of the circumstances under which they were made, not misleading, or

(c) to engage in any act, practice, or course of business which operates or would operate as a fraud or deceit upon any person,

in connection with the purchase or sale of any security.

The rule provides a broad framework within which the SEC and the courts may prohibit any practice or device which they might deem unfair. ${ }^{12}$ Judicial statements have been made that, under these provisions:

It is unlawful for an insider, such as a majority stockholder, to purchase the stock of minority shareholders without disclosing material facts affecting the value of the stock, known to the majority stockholder by virtue of his inside position but not known to the selling minority stockholders, which information would have affected the judgment of the sellers. ${ }^{13}$

While statements of this type may be interpreted as imposing liability under certain circumstances for total nondisclosure, each of the decisions involved half-truths which provided an alternative basis for liability. ${ }^{14}$ In Joseph $v$.

8. Corporate insiders have been defined as officers, directors, and "every person who is directly or indirectly the beneficial owner of more that 10 per centum of any class of any equity security ...." Securities Exchange Act of 1934, § 16(a), 48 Stat. 896 (1934), 15 U.S.C. $\$ 78 p(a)$ (1958).

9. Strong v. Repide, 213 U.S. 419 (1909). See Ballantine, CoRporations 213 (rev. ed. 1946); Comment, The Prospects for Rule X-10B-5: Au Emerging Remedy for Defrauded Investors, 59 Y ALE L.J. 1120, 1125 (1950); Comment, 39 CaLIF. I. Rev. 429, 430-31 (1951).

10. 17 C.F.R. $\$ 240.10 b-5$ (1949).

11. 48 Stat. 891 (1934), 15 U.S.C. $\$ 78$ j (b) (1958).

12. The term "fraud" as employed in the context of the securities acts was intended to be "not limited to common law concepts, but includes all deceitful practices contrary to the plain rules of common honesty." Loss, The SEC and The Broker-Dealer, 1 VAND. I. Rev. 516, 517 (1948), citing People v. Federated Radio Corp., 244 N.Y. 33, 38, 154 N.E. $655,657-58$ (1926).

13. Speed v. Transamerica Corp., 99 F. Supp. 808, 828-29 (D. Del. 1951).

14. Kardon v. National Gypsum Co., 73 F. Supp. 798 (E.D. Pa. 1947) ; Fry v. 
Farnsworth Radio \& Television Corp., ${ }^{15}$ the one case which involved total nondisclosure, the question of fraud was not reached; the case was dismissed on the ground that privity was lacking between the parties. ${ }^{10}$ The judge expressed the opinion that there had clearly not been a violation of subsections (a) and (b), but he acknowledged that, had privity existed, there might still have been a violation of subsection (c).$^{17}$ None of the cases suggests that any duty of affirmative disclosure should extend beyond corporate insiders.

Persons acting in the dual capacities of broker and dealer, however, have been held liable for failure to disclose their dual role. ${ }^{18}$ Although this liability may be founded in part on a fiduciary relationship concept similar to that applied to insiders, it appears to be primarily based upon a theory of implied misrepresentation: because persons dealing with a broker will ordinarily assume that he is acting solely as an agent, nondisclosure of his additional role as a principal constitutes a misleading omission. ${ }^{10}$ Broker-dealers, moreover, have been held to an affirmative duty of disclosure where they were effecting transactions for insiders who they knew to be in passession of nonpublic material information. ${ }^{20}$ These cases, however, rather than imposing liability on the grounds of a fiduciary relationship, have apparently viewed the brokers as conspirators in the insiders' scheme to defraud. ${ }^{21}$

The recent decision by the SEC, In the Matter of Cady, Roberts $\&$ Co., ${ }^{22}$ may have expanded in several respects the scope of liability for total nondisclosure. On the morning of November 25, 1959, the directors of CurtissWright Co. met to discuss the quarterly dividend of the company's common stock. Among the directors was J. Cheever Cowdin, a registered representative of the brokerage firm of Cady, Roberts \& Co. At approximately 11:00 a.m. the board, in compliance with a New York Stock Exchange rule, ${ }^{23}$

Schumaker, 83 F. Supp. 476 (E.D. Pa. 1947); Charles Hughes \& Co. v. SEC, 139 F.2d 434 (2d Cir. 1943).

It should also be noted that these transactions involved face-to-face purchases from persons already shareholders.

15. 99 F. Supp. 701 (S.D.N.Y. 1951).

16. It appeared that plaintiffs had purchased their stock on the market long after the defendants had sold the last of their stock, so that there was no possibility that the defendants could have sold to the plaintiffs. Id. at 706.

17. Ibid.

18. E.g., Charles Hughes \& Co. v. SEC, 139 F.2d 434 (2d Cir. 1943); Hughes v. SEC, 174 F.2d 969 (D.C. Cir. 1949) ; Hughes \& Treat, 22 S.E.C. 623 (1946). These cases were brought under $\$ 15$ of the Securities Exchange Act of 1934, 48 Stat. 893 (1934), 15 U.S.C. $\S 78(o)(1958)$.

19. For a thorough discussion of this facet of the broker-client relationship, see SEC, Report on The feasibility and Advisability of the Conplete Segregation of the FunCtIONS OF DEALER AND BRoker at xiv-xvi (1936).

20. Fry v. Schumaker, 83 F. Supp. 476 (E.D. Pa. 1947); William I. Hay, 19 S.E.C. 397 (1945).

21. See, e.g., Fry v. Schumaker, 83 F. Supp. 476, 478 (E.D. Pa. 1947); In re Van Alstyne, Noel \& Co., 33 S.E.C. 311,339 (1952).

22. SEC Securities Exchange Act Release No. 6668, November 8, 1961.

23. New York Stock Exchange, Company Manual, Article III(4), Current Form of Listing Agreement, p. A-28 (1958). 
authorized transmission to the Exchange of the information that the dividend had been cut from $\$ .625$ to $\$ .375$ per share. A typing problem delayed the transmission of the telegram, and the announcement, although transmitted to Western Union at 11:12 a.m., did not reach the Exchange until 12:29 p.m. Ordinarily, this procedure would have been completed by approximately $11: 30$ a.m. ${ }^{24}$ It was also customary for a telegram to be sent to the Dow Jones Ticker Service; but, "apparently through some mistake or inadvertence," the message did not reach the service until $11: 45 \mathrm{a} . \mathrm{m}$. and announcement of the dividend cut did not appear on the Dow Jones Ticker Tape until 11:48 a.m. After the dividend action, and after the Secretary of Curtiss-Wright had been sent out to notify the Exchange and Dow Jones, the meeting was recessed. Cowdin immediately telephoned the offices of Cady, Roberts \& Co. and left a message for a partner in the firm, Robert Gintel, that the dividend had been cut. Gintel, in the two days prior to the dividend meeting, had been selling Curtiss-Wright stock, and had disposed of 6,500 shares, 4,300 of which had been sold on the morning of November 25, but prior to 11:00 a.m. Upon receipt of the dividend information, ${ }^{25}$ he placed two additional sell orders for discretionary accounts ${ }^{26}$ one to sell 2,000 shares for 10 accounts, the other to sell short 275,000 shares for 11 accounts. These orders were executed approximately half an hour before announcement of the dividend cut appeared on the ticker; they were put through at $40 \mathrm{I} / 4$ and $403 / 8$. Shortly after the dividend announcement appeared on the ticker, the Exchange suspended trading in Curtiss-Wright. When trading was resumed two hours later, the stock opened at $36 \mathrm{I} / 2$, and closed for the day at $347 \%$. Gintel was fined $\$ 3,000$ by the Exchange for the transactions, and was subsequently suspended from the New York Stock Exchange for 20 days as the result of administrative action brought against him by the SEC for violation of rule $10 \mathrm{~b}-5.28$ No attempt was made by purchasers of the stock to hold Gintel civilly liable. ${ }^{29}$

24. Letter from Mr. Joseph G. Connolly, New York attorney. (On file in the Yale Law Library.)

25. Gintel, of course, knew that the information had been received from Cowdin and that Cowdin was an insider in Curtiss-Wright. SEC Securities Exchange Act Release No. 6668 , p. 3.

26. A discretionary account is one for which the broker has the power to conduct transactions at his discretion without first obtaining the specific permission of the account holder. See Leffrer, The Stock Market 166-67 (2d ed. 1957).

27. The short sales involved were "against the box," i.e., they were sold against the firm's holdings, and the sales were covered later from specific accounts. Thus, when Gintel covered all of the discretionary holdings, he found himself with 950 shares uncovered, and these he allocated to his wife, bringing her total to 1,450 shares. SEC Securities Exchange Act Release No. 6668, p. 11 n.30.

28. The SEC action was brought under $\S 19$ (a) (3) of the Securities Exchange Act, 48 Stat. 898 (1934), 15 U.S.C. § 78s(a) (3) (1960). The remedies available to the SEC were imposition of a fine and/or suspension from the exchange.

29. See note 35 infra and accompanying text. 
The Commission, in the Cady, Roberts case, devotes a major portion of its opinion to establishing the scope of the insider's affirmative duty of disclosure. It holds that this duty is not limited to face-to-face transactions, ${ }^{30}$ nor is it limited to the traditional "fiduciary relationship" situation of purchases from existing shareholders; it arises out of any sale of stock. ${ }^{31}$ The Commission then goes on to state that this special obligation is not restricted to corporate insiders, but has instead as its basis :

first, the existence of a relationship giving access, directly or indirectly, to information intended to be available only for a corporate purpose and not for the personal benefit of anyone, and second, the inherent unfairness involved where a party takes advantage of such information knowing it is unavailable to those with whom he is dealing. ${ }^{32}$

The SEC does not fully clarify its reasons for applying this rule to Gintel. It seems to focus primarily on his partnership in a firm with which his informant, clearly a corporate insider, was associated. ${ }^{33}$ The Commission appears also to be influenced by the fact that Gintel was a stockbroker. ${ }^{34}$ His liability is analogized to that of a broker who effects transactions for an insider with knowledge that the insider possesses non-public material information. Finally, having established the duty of disclosure, the Commission points

30. The distinction between face-to-face transactions and those effected on a securities exchange stems from the holding in Goodwin v. Agassiz, 283 Mass. 358 (1933), that a director need not disclose material inside information in dealings on an open securities market. This view, however, has become increasingly unacceptable: "Dishonest directors should not find absolution from retributive justice by concealing their identity from their victims under the mask of the stock exchange." Ballantine, Corporations 216 (rev. ed. 1946).

31. In the past, there has been some argument, derived from the common law, that purchases and sales are distinguishable because a director stands in a fiduciary relationship only to those who are existing shareholders. In Cady, Roberts, registrant cites Hotchkiss v. Fischer, 136 Kan. 530, 16 P.2d 531 (1932), in support of its contention that a fiduciary duty exists only between insiders and sellers. The Commission, however, points out that this is no longer the case, noting that, in 16 Fed. Reg. 7928 (1951), the words "by a purchaser" had been specifically stricken from the title of rule $10 \mathrm{~b}-5$, so that it simply read, "Employment of manipulative and deceptive devices." Further, citing Judge Learned Hand, in Gratz v. Claughton, 187 F.2d 46 (2d Cir. 1951), cert. denied, 341 U.S. 920 (1951), the Commission states that "there is no valid reason why persons who purchase stock from an officer, director, or other person having the responsibilities of an 'insider' should not have the same protection afforded by disclosure of special information as persons who sell stock to them." Securities Exchange Act Release No. 6668, p. 9.

32. $I d$. at 6 .

33. Id. at 7.

34. In response to the argument that "any requirement that a broker-dealer make disclosure of 'adverse factors disclosed by his own analysis' would create uncertainty and confusion," the Commission states that there could be no uncertainty concerning the type of information involved in the facts of Cady, Roberts, but does not deny the existence of broker liability. SEC Securities Exchange Act Release No. 6668, p. 10. It is true, however, that this in itself only suggests that a broker may be under a general duty of disclosure, not that such a duty is based on the fact that he is a broker. 
out that the prohibited transactions include trading for discretionary accounts and execution of orders, not merely trading for one's own account.

The SEC's imposition of a broad duty of disclosure on insiders is reasonable as a matter of policy and sufficiently supported by the precedents. Given this duty, imposition of administrative sanctions ${ }^{35}$ on Gintel because of his business relationship to Cowdin can be justified on what may be termed a "one economic unit" theory; in certain situations, two or more persons may be members of a single economic unit such that profits resulting from action by any one of them will accrue to the group as a whole, not to the individuals separately. It has been held that, where the law forbids short-swing transactions by an insider in the securities of his corporation, this prohibition will extend to his wife, for the benefit in either case would accrue to the same economic unit. ${ }^{36}$ The present situation would seem somewhat analogous: the benefit that would have accrued to Cowdin, had he undertaken the transactions involved, would have come through increased customer goodwill to the firm. And the same result was achieved through Gintel's trading on the basis of Cowdin's information. ${ }^{37}$ The use of this business relationship as a basis for Gintel's subjection to disciplinary action might be justified more simply on Gintel's "special access" to the information on which he allegedly acted. Numerous types of business relationships, other than that existing in the Cady, Roberts situation may, of course, produce the same effect, and it would be impossible to police them all. It does not seem unreasonable, how-

35. The imposition of civil liability by private parties might, of course, present several difficulties not involved in the present situation and beyond the scope of this Note. One would have to consider, for example, whether particular persons had been injured; also whether the broker should be forced to repair the injury even though he did not himself receive the "excess profit."

36. See Broffe v. Horton, 172 F.2d 489, 494 (2d Cir. 1949); 2 Loss, Securities Regulation 1101 (2d ed. 1961).

Such transactions are prohibited by $\$ 16(\mathrm{~b})$ of the Securities Exchange Act of 1934, 48 Stat. 896 (1934), 15 U.S.C. \& 78p(b) (1958), which provides that:

for the purpose of preventing the unfair use of information which may have been obtained by such beneficial owner, director, or officer by reason of his relationship to the issuer, any profit realized by him from any purchase and sale, or any sale and purchase, of any equity security of such issuer ... within any period of less than six months ... shall inure to and be recoverable by the issuer ....

37. While the ultimate result of this increased customer goodwill will be greater profits for the partners, it is not presently feasible to allocate the benefit to individuals. Thus evasion cannot be prevented by simply making Cowdin, the insider, return his share of the benefit. Compare Rattner v. Lehman, 98 F. Supp. 1009 (S.D.N.Y. 1951), aff'd., 193 F.2d 564 (2d Cir. 1952). In that case, a partnership, without the knowledge of one of the partners who was a director of a corporation, bought and sold stock in that corporation at a profit, and after the partner-director learned of the transaction, he paid over to the corporation his share of the profits from the transaction. It was held that a stockholder, suing on behalf of himself and all other stockholders, could not recover on behalf of the corporation from any of the partners the remainder of the profit realized from the transaction. 
ever, to single out certain formalized relationships which are particularly likely to provide such access. ${ }^{38}$ This is especially true where the participants are brokers, for such persons play an important role in the operation of the securities market and also are likely to make extensive use of inside information.

A different, and perhaps more difficult, problem is presented if Gintel was held subject to discipline solely because of his position as a broker. "Special access" might again provide a justification. ${ }^{39}$ An inequitable situation might result, however, since other investors, with perhaps equal access, are placed under no such duty. ${ }^{40} \mathrm{~A}$ more satisfactory ground for holding the broker may be found by focusing on his position as a part of the policing mechanism of the stock market. It has long been recognized that the standards of the "horse trade" are inappropriate to a large, impersonal securities market. This rule has been reflected not only in strict governmental regulation, but also in the responsibilities assumed by those groups who carry on the operations of the market. Cady, Roberts \& Co. is a member of both the New York Stock Exchange and the National Association of Securities Dealers. ${ }^{41}$ Each of these organizations is governed by a code of fair practices, regulated not by common law principles, but by the more stringent standards of "fair dealing." 42 Extensive policing functions have been undertaken by the exchanges under these codes with the purpose of buttressing public confidence in the market as a place where fair play and discipline are normal procedures. ${ }^{43}$

38. While every industry might provide its members with special access to information regarding the other companies in that industry, the brokerage business is one in which information itself is a prime commodity.

39. Corporate insiders are usually in the best position to obtain information concerning a security's worth. Brokers and dealers, though less favorably situated, are in a position far superior to that of the ordinary investor. Therefore, the corporate insider and the corporation may have a broader duty to disclose than that owed by independent brokers and dealers, who in turn have a broader duty than that owed by the ordinary in-and-out investor, who may in their [sic] turn have no higher duty to disclose than that imposed by common law, which was usually no duty at all.

Comment, The Prospects for Rule 10b-5: An Emerging Remedy for Defraudcd Investors, 59 Y ALE L.J. 1120, 1143 (1950).

40. See Testimony of P. T. Byrne, Regional Administrator, SEC, New York, N.Y. Hearings on the Securities and Exchange Commission before a Subcomnittee of the House Committee on Interstate and Foreign Commerce, 82d Cong., 2d Sess. 725-26 (1952).

41. The National Association of Securities Dealers, an organization similar in most respects to the New York Stock Exchange, regulates the activities of those broker-dealers who trade in securities on the over-the-counter market.

42. The purpose of the NASD Rules of Fair Practice is stated to be ". . . to cope with those methods of doing business which, while technically outside the area of definite illegality, are nevertheless unfair both to customer and to decent competitor, and seriously damaging to the mechanism of the free and open market." NATIONAL Assocration of Securities Dealers, Rules of Fatr Practice E-131(1958).

43. As mentioned in text at note 28, supra, the New York Stock Exchange imposed a $\$ 3,000$ fine in the present case long before any disciplinary action by the SEC. It was 
In this context, it would seem appropriate for the SEC to impose upon the broker a duty of disclosure not imposed upon the ordinary investor. Moreover, the sanction applied by the SEC-suspension of Gintel from the Exchange for a period of twenty days-is particularly fitting to a "policing function" theory of liability.

The scope of the insider's duty has been defined in quite general terms as one to disclose information known to him through his relationship to the corporation but not known to the public and which, if known, would influence investors' actions. ${ }^{44}$ It is true that some uncertainty is created by the vagueness of this standard and that this uncertainty may be greater in some respects for the broker than for the corporate insider. It may also have more serious consequences for the broker, because the insider is precluded, at most, from trading in the securities of his own corporation, ${ }^{45}$ whereas the broker may be foreclosed from trading in any securities about which he has received inside information. It would seem, however, that administration of the rule need not prove unworkable if practical considerations guide its application. ${ }^{46}$ Upon receiving information from any source, a broker will ordinarily be faced with three basic questions:

(1) Is the information true, or merely rumor or opinion?

(2) Is it information which would have a significant effect on the price of a security?

(3) Is it already sufficiently available to the public that no further disclosure would be required?

None of these questions presented any problem under the peculiar facts in Cady, Roberts: there was little doubt as to the truth of the information received by Gintel; the importance of the dividend information was clearly reflected by the Exchange's requirement that such information be immediately reported by the issuer; ${ }^{47}$ and the reporting requirement would likewise seem to have solved the problem of ascertaining whether the particular information was public. ${ }^{48}$

explicitly stated by the Commission that this fact caused its penalty to be considerably lighter than it would otherwise have been. SEC Securities Exchange Act Release No. 6668, pp. $12-13$.

44. See note 14 supra.

45. The corporate insider is relatively free to trade on information received from associates in other corporations in exchange for information concerning his own corporation. See Hearings, supra note 40, at 725-26. But see Blau v. Lehman, 30 U.S.L. WeEK 4125 (U.S. Jan. 22, 1962).

46. The alternative, a rigidly defined rule, probably could not be drafted so as to be effective without definitions so complex as to render the rule unworkable.

47. See note 23 supra and accompanying text.

48. The SEC assumed that Gintel knew that the information was not yet on the ticker. Had they not made this assumption, there might have been some question as to the fairness of imposing liability because of the improbability, at the time when Gintel sold, that such information would not be on the tape. However, it would perhaps not be unreasonable to hold that a broker can not raise, as a defense, a defect in some other part 
The abovementioned questions, however, might present certain problems in fact situations more common than that which occurred in Cady, Roberts. The broker, unlike the corporate insider, is always dealing with relayed, or second-hand information, and he may often have difficulty evaluating the reliability of that information. A broker should not be held responsible, therefore, unless the information (1) concerns material occurrences which are facts, not conjecture (i.e., those events which have already occurred, and are not merely likely to occur in the future), ${ }^{49}$ and (2) is given by someone who the broker has good reason to believe is an insider. ${ }^{50}$

Once a broker has determined that a given item of information is reliable, he must decide whether it is sufficiently material to warrant disclosure. Because of his expertise in the dynamics of the securities market, the broker should be in a unique position to estimate the effect that the information would have on the market. Thus, for most of the information which a broker receives, the exercise of his discretion will determine whether it is to be disclosed. A fairly specific rule might be devised, however, for those types of information which it is felt will always require disclosure. ${ }^{51}$

The third question which a broker must answer-whether the information is sufficiently unavailable to the public that its use would be unfair-would present serious problems were it applicable to all the information received from various sources by the broker. For, unlike the insider, the broker is removed from the source of the information; he does not have the same ability to determine the extent to which the information has been made available to the public. But if the broker's duty were limited to information received from an insider, the problem would be manageable. Not only would this restriction limit the occurrence of the problem; it would also confine it to situations where it could be most easily handled, for the broker should be able to ascer-

of the policing machinery, but must check the matter himself especially where the effort necessary is so slight.

49. Brokers will then not be faced with the difficult task of evaluating the reliability of insider predictions which, albeit well intentioned, are simply the well-informed guesses of individuals and might differ substantially from guesses made by other individuals in a similar position.

50. These limitations would also tend to eliminate the likelihood of a flood of rumors being disseminated over the ticker.

The problem of determining who is an insider is not as difficult as it might appear. The New York Stock Exchange requires every firm to possess fairly complete data on the business connections of its clients (or their spouses), which makes it easy to determine who is a corporate officer or director, and the SEC requires that all major beneficial owners of equity securities register their holdings with the Commission. See Leffler, The Stock Market (2d ed. 1957); Securities Exchange Act, § 16(a), 48 Stat. 896 (1934), 15 U.S.C. \& 78p (a) (1958).

51. In addition to its rule on dividend information (see note 23 sipra), the Exchange requires immediate reporting of certain other corporate events, e.g., redemption or cancellation of issues; corporation's purchase of its own securities, etc. See NEw York Stock Exchange, Company Manual, Current Form of Listing Agreement, pp. A-18 to A-28 (1958). 
tain from his inside source the extent to which the information has been made public.

Finally, one might consider the range of activities for which disclosure may be required. One aspect of this problem is whether the possibility of disciplinary action will effectively force a broker in possession of inside information to make disclosure before carrying through transactions which he would have undertaken without such knowledge. A broker who has determined, through his own financial analysis, that a security is ripe for purchase or sale may find that receipt of certain information regarding that security will bar him from taking action without disclosure, even though the inside information served only to confirm an independently reached decision. The SEC in Cady, Roberts intimated that a broker might not be disciplined for implementing a decision arrived at prior to the aquisition of the inside information. But the facts in the case illustrate the difficulty of obtaining the proof necessary for exculpation under such a theory. Gintel had commenced a series of sales prior to receipt of the information, and yet he was unable to make a convincing argument against the imposition of liability. ${ }^{52}$ In situations where the broker has merely made a decision prior to receipt of the inside information, but has taken no action on his decision, the SEC rule is tantamount to the imposition of an absolute liability. Imposition of penalties in such cases might seem unfair, since the broker has not really made use of any inside information. But the goals to be achieved by strict regulation of the securities market ${ }^{53}$ are sufficiently important to warrant the occasional payment of this price. Further, it is consistent with the concept of the broker as a guardian of the securities market that there be times when his duty as a policeman override his duty to his customers and their right to the benefits of his analysis. ${ }^{54}$ It might even be argued that the broker is under an obligation to make certain that information which should be made public is in fact made public and that mere nondisclosure would constitute a breach of his duty. ${ }^{55}$ The very fact that, as a broker, he is especially likely to discover information before it becomes public, argues in favor of imposing such special duties on the broker as a policeman of the securities markets.

52. Gintel had disposed of 4,300 shares of Curtiss-Wright prior to 11:00 a.m. on November 25, and sold an additional 7,000 shares after 11:00. Thus, he was unable to sustain the burden of proof even though he had already disposed of almost $40 \%$ of his day's total before receipt of the information.

53. See note 42 supra and text at note 43 supra.

54. SEC Securities Exchange Act Release No. 6668, p. 12. Thus, it would appear that there are times when "a policeman's lot is not an 'appy one." Gilbert \& Sullivan, The Pirates of Penzance (1880).

55. Since the information, but for a fault in the system, would be public, the broker would be no worse off in this case than any investor who has decided to sell a stock, and who, before he can act on his decision, watches it lose its value as a news item concerning that security appears on the ticker. No one would contend that such an investor was deprived unjustly of any profit. 
Another aspect of the problem concerns the degree of broker participation in a transaction necessary to warrant disclosure. A continuum of possible situations exists, ranging from the broker's trading for his own account, at one extreme, to his doing nothing with the information, at the other. For purposes of analysis, however, it may be satisfactory to examine the following situations :

(1) Trading by the broker for his own account on the basis of the information;

(2) Trading for discretionary accounts (the situation in the present case) ;

(3) Offering advice to a client, who then makes the final decision as to whether a transaction will be undertaken; and

(4) Excuting a buy or sell order for a client without proferring any information.

Assuming that there is to be some duty of disclosure, it should, of course, apply in the case where a broker is trading for himself. ${ }^{56}$ Imposition of the duty in situation (2) would seem equally sound, for the broker is again the motivating force in a transaction where one side realizes a gain as the result of the misuse of information not available to the other. It is true that the broker is not himself making a direct profit, but even if this might render civil liability inappropriate, it should not make disciplinary action unreasonable. ${ }^{57}$ This is especially true since the broker is still acting in a business context, presumably for the purpose of creating customer goodwill and increasing commissions. The same justifications would seem to apply to situation (3), even though the broker is not now the sole motivating factor. Situation (4) presents a difficult problem. It may be argued that a broker in such a case has acted merely as an agent, and that his inside information should not be considered since it was not conveyed, and therefore played no role in the transaction. But non-public information possessed by a broker will in all likelihood play some role, albeit indiscernible, in any transaction to which he is an advisor. The most satisfactory solution, therefore, would be to place upon the broker a duty to disclose all material inside information as soon as he practically can. ${ }^{58}$

It is impossible to predict with any certainty how far the SEC will in practice carry the implications of the Cady, Roberts case. The decision, of course, might be held applicable solely to one in the dual capacity of a broker and the business partner of an insider, and then only if he acts on information which, under an established rule, requires immediate public disclosure and obviously should not have been received by him prior to such publication. Such a reading, however, is too narrow. While the language of the opinion does not clearly indicate that the SEC intends to impose special duties on the broker as

56. See note 18 supra.

57. See note 35 supra.

58. This should mean that the broker is not to wait until the occassion of a transaction arises, but should report the information when it comes to his attention. 
such, ${ }^{50}$ the decision has apparently been viewed in business circles as strongly suggestive of such a policy. Taken in the context of other recent SEC tendencies to impose stricter standards upon brokers, ${ }^{60}$ it does suggest that the broker should not regard himself as being in the position of an ordinary investor; he would be well advised to act on the assumption that he is exposed to the risk of penalties for total nondisclosure. The more difficult question concerns the range of types of information and activities which the prohibition will encompass. While the SEC confined itself to a holding on the narrow situation in the present case, ${ }^{61}$ it is likely that the Cady, Roberts decision is a warning that it will move in the direction of expanding the scope of liability.

59. See text at notes $33 \& 34$ sipra.

60. E.g., Berko v. SEC, CCH Fed. Sec. L. Rep. If 91115 (2d Cir., Dec. 7, 1961); Kahn v. SEC, CCH FED. SEc. L. REP. If 91116 (2d Cir., Dec. 7, 1961); SEC v. Aldred Inv. Trust $e t$ al., No. 2885 (S.D.N.Y., Aug. 11, 1961).

61. SEC Securities Exchange Act Release No. 6668, p. 1. 